\title{
TREATMENT OF KITCHEN WASTE BY MICROBIAL CULTURE
}

\author{
Anuradha.S.Tanksali ${ }^{1}$, Sridevi.S.Angadi ${ }^{2}$, Asha.Arwikar ${ }^{3}$ \\ ${ }^{1}$ BLDEA's V.P.P.G.H College of Engineering and Technology, Bijapur-586103, India. \\ ${ }^{2}$ BLDEA's V.P.P.G.H College of Engineering and Technology, Bijapur-586103, India. \\ ${ }^{3}$ BLDEA's V.P.P.G.H College of Engineering and Technology, Bijapur-586103, India.
}

\begin{abstract}
The sight of a dustbin overflowing and the stench rising from it are all too familiar sights of a crowded city. As we cross it, we look away from it and hold our nose. If we give a thought to it, we also have a role to play in the creation of this stench. We can also play a role in the lessening of this smell and reducing the dumping of the waste, if we follow proper methods of disposal of the waste generated in the house.
\end{abstract}

The growth of urban cities and ever increasing human population and the misuse and abuse of the environment has led to increased accumulation of waste materials which is polluting water, air, soil and increased risk to human life in the form of epidemics.

There are number of methods for solid waste management from ancient times. Some of the methods are sanitary land-fill, vermicomposting, burning, incineration, biogas generation, anaerobic composting. These methods will not prove effective in some of the circumstances such as high temperature, high moisture content. So, there is need to find such a method which suites to all the environmental conditions \& circumstances.

The above said problems can be solved by the new method of waste management viz. Mechanical Biological treatment (MBT). In this method, the culture called mega-bacillus is considered as key agent for degradation of organic waste.

In the present study, kitchen waste is decomposed using mega-bacillus. A total quantity of $20 \mathrm{~kg}$ green waste was converted to 4.074 $\mathrm{kgs}$ of manure in just 16 days with a pH of 7.96, $C: N$ ratio of 25.07:1 and a Nitrogen content of $2.15 \%$ which are within the desirable parameters for increasing the yield of crop \& maintaining the fertility of soil.

Keywords: Biological treatment, Solid waste, Aerobic composting, Compost.

\section{INTRODUCTION}

\subsection{Health Impacts of Solid Waste (5)}

Modernization and progress has had its share of disadvantages and one of the main aspects of concern is the pollution it is causing to the earth - be it land, air, or water. With increase in the global population and the rising demand for food and other essentials, there has been a rise in the amount of waste being generated daily by each household. This waste is ultimately thrown into municipal waste collection centres from where it is collected by the area municipalities to be further thrown into the landfills and dumps. However, either due to resource crunch or inefficient infrastructure, not all of this waste gets collected and transported to the final dumpsites. If at this stage the management and disposal is improperly done, it can cause serious impacts on human health and problems to the surrounding environment.

The group at risk from the unscientific disposal of solid waste include - the population in areas where there is no proper waste disposal method, especially the preschool children; waste workers; and workers in facilities producing toxic and infectious material. Other high-risk group includes population living close to a waste dump and those, whose water supply has become contaminated either due to waste dumping or leakage from landfill sites. Uncollected solid waste also increases risk of injury, and infection.

\subsection{Occupation Hazards Associated with Waste}

\section{Handling (5)}

\subsubsection{Infections}

a) Skin and blood infections resulting from direct contact with waste, and from infected wounds

b) Eye and respiratory infections resulting from exposure to infected dust, especially during landfill operations

c) Different diseases that result from the bites of animals, feeding on the waste

d) Intestinal infections that are transmitted by flies, feeding on the waste 


\subsubsection{Chronic Diseases}

a) Incineration operators are at risk of chronic respiratory diseases, including cancers resulting from exposure to dust/ash and hazardous compounds

\subsubsection{Accidents}

a) Bone and muscle disorders resulting from the handling of heavy containers

b) Infecting wounds resulting from contact with sharp objects

c) Poisoning and chemical burns resulting from contact with small amounts of hazardous chemical waste mixed with general waste.

d) Burns and other injuries resulting from occupational accidents at waste disposal sites or from methane gas explosion at landfill sites.

\section{IMPORTANCE OF WASTE REDUCTION (5)}

In the affluent countries, the main motivations for waste reduction are frequently related to the high cost and scarcity of sites for landfills, and the environmental degradation caused by toxic materials in the deposited wastes. The same considerations apply to large metropolitan areas in developing countries that are surrounded by other populous jurisdictions. The places that currently do not have significant disposal pressures can still benefit from encouraging waste reduction. Their solid waste departments, already overburdened, cannot afford to spend more money and effort on the greater quantities of wastes that will inevitably be produced as consumption levels rise and urban wastes change.

Solid waste managers in developing countries tend to pay little attention to the topic of reducing non-organic wastes because the wastes they collect are between $50 \%$ to $90 \%$ organics, dirt and ashes. These municipal wastes, however, are amenable to composting or digestion, provided they contain very low levels of synthetic materials. Solid waste departments thus have an interest in promoting diversion of synthetic recyclables from the waste stream.

Each household generates garbage or waste, day in and day out. Items that are no longer needed or do not have any further use, fall in the category of waste and we tend to throw them away. There are different types of solid waste depending on their source. In today's polluted world, learning the correct methods of handling the waste generated has become essential. Segregation is an important method of handling municipal solid waste. Segregation at source can be understood clearly by schematic representation. One of the important methods of managing and treating wastes is composting. As the cities are growing in size and in numbers problems such as the generation of plastic waste, various municipal waste treatment and disposal methods are now being used for trying and resolving these problems. One common sight in all cities is the rag picker who plays an important role in the segregation of this waste. Garbage generated in households can be recycled and reused to prevent creation of waste at source and reducing amount of waste thrown into the community dustbins.

\subsection{Four Rs Concept for Waste Management (5)}

\subsubsection{Refuse}

Instead of buying new containers from the market, use the ones that are in the house. Refuse to buy new items though you may think they are prettier than the ones you already have.

\subsubsection{Reuse}

Do not throw away the soft drink cans or the bottles; cover them with homemade paper or paint on them and use them as pencil stands or small vases. Alternately, you can store them and sell it to the kabariwalla who takes these for recycling. Reuse the plastic bags for shopping again and again. It is better if you use shopping bags made of cloth or jute, which can be used over and over again.

\subsubsection{Recycle}

Segregate your wastes so that non-perishable wastes are easily collected and taken for recycling. Dig a small pit to compost your organic wastes like kitchen wastes at your home.

\subsubsection{Reduce}

Reduce the generation of unnecessary waste, e.g. carry your own shopping bag when you go to the market and put all your purchases directly into it.

\section{METHODS OF SOLID WASTE MANAGEMENT}

(6) (10)

\subsection{Open Dumping}

The solid waste generated in the society is dumped in the open place outside the premises of the city. The following are the disadvantages of this method:-

a) Bad smell \& odour.

b) Air pollution.

c) Environmental problems.

d) Requirement of large area.

\subsection{Open Burning}

In this method the collected waste is dumped in open ground $\&$ then it is burnt. The disadvantages of this method are:-

a) Burning creates bad smell.

b) As waste is burnt it leads to air pollution which affects the ozone layer, as it contains lot of harmful gases. 
c) Smoke generated from burning causes respiratory problems in humans.

d) Affects the fertility of soil.

e) Creates huge amount of ash for which another disposal methods should be found.

\subsection{Sanitary Landfill}

The sanitary landfill can be described as engineered burial of waste. Sanitary landfill is defined as a method of disposing of waste on land without creating nuisance or hazard to public health or safety, by utilizing the principals of engineering to confine the waste to the smallest practical area \& reduce it to smallest practical volume \& to cover it with layer of earth at the conclusion of each days operation or at such more frequent intervals as may be necessary. The disadvantages of sanitary landfill are:-

a) The microbial degradation is at a very slow rate when compared with the other biological treatment systems.

b) When too much organic matter is buried without consideration for methane production, there is possibility of potential fire hazard.

c) When there is less than $60 \%$ moisture, it is difficult for bacteria to grow.

d) There is production of carbon-di-oxide which is troublesome due to its density.

e) Lot of land fill gases are emitted which are to be handled.

f) There is release of leachate, leading of pollution of surface $\&$ ground water.

g) The land used for filling cannot be reused for a longer time.

h) The waste after treatment does not have any reusable value.

\subsection{Incineration}

Incineration is a waste treatment process that involves the combustion of organic substances contained in waste materials. Incineration and other high temperature waste treatment systems are described as "thermal treatment". Incineration of waste materials converts the waste into ash, flue gas, and heat. The ash is mostly formed by the inorganic constituents of the waste, and may take the form of solid lumps or particulates carried by the flue gas. The flue gases must be cleaned of gaseous and particulate pollutants before they are dispersed into the atmosphere. In some cases, the heat generated by incineration can be used to generate electric power. The disadvantages of this method are:-

a) The highly toxic ash must be safely disposed off. Additional landfill is required.

b) Incinerators emit varying levels of heavy metals such as Vanadium, Manganese, Chromium, Nickel, Arsenic, Mercury, Lead and Cadmium, which can be toxic even at very minute levels. c) Building and operating waste processing plants such as incinerators requires long contract periods to recover initial investment costs, causing a long term lock-in period.

d) Some incinerators are visually undesirable.

\subsection{Bio-gas (Anaerobic composting process)}

Biogas typically refers to a gas produced by the biological breakdown of organic matter in the absence of oxygen. Organic waste such as dead plant and animal material, animal faeces, and kitchen waste can be converted into a gaseous fuel called biogas. Biogas originates from biogenic material and is a type of bio-fuel. Biogas is produced by the anaerobic digestion or fermentation of biodegradable materials such as biomass, manure, sewage, municipal waste, green waste, plant material, and crops. Biogas comprises primarily methane $\left(\mathrm{CH}_{4}\right)$ and carbon dioxide $\left(\mathrm{CO}_{2}\right)$ and may have small amounts of hydrogen sulphide $\left(\mathrm{H}_{2} \mathrm{~S}\right)$, moisture and siloxanes. The gases methane, hydrogen, and carbon monoxide $(\mathrm{CO})$ can be combusted or oxidized with oxygen. Biogas can be used as a fuel for any heating purpose, such as cooking. It can also be converted to electricity. Along with the advantages there are disadvantages of Bio-gas which are listed below:-

a) Biogas contains contaminant gases which can be corrosive to gas engines and boilers.

b) Digestate must meet high standards in order to be used on land without

detrimental, effects on agricultural uses especially food crops.

c) Produces a limited quantity of energy and is dependent upon location. The plant needs to be established near to feedstock and energy users.

d) There is little or no control on the rate of gas production, although the gas can, to some extent be stored and used as required.

e) Biogas needs to be cleaned of $\mathrm{H}_{2} \mathrm{~S}$ prior to power generation.

f) Compost needs dewatering \& drying before use.

i) Requires skilled labour \& supervision.

j) It works costly due to the establishment of digester, dewatering \& biogas cleaning system.

\subsection{Composting}

Composting is very similar in its action to a sanitary land fill but is a controlled microbial reaction yielding a stable end product much sooner. Composting is a method in which putresible organic matter in the refuse or solid waste is digested aerobically \& converted into humus \& stable mineral compounds. Composting removes the readily degradable organic matter from the garbage \& produces a stable material (Nitrogen rich manure) that can be used to recover waste land or to grow food crops through the bacterial agencies.

Bioconversion of organic resides is carried out by different groups of heterotrophic micro-organisms (bacteria, fungi, 
acitinomycetes \& protozoa). The organic material present in the municipal wastes can be converted into stable form either aerobically or anaerobically.

In case of aerobic decomposition micro-organisms oxidized organic compounds to $\mathrm{CO}_{2}, \mathrm{NO}_{2}$ and $\mathrm{NO}_{3}$. Here carbon is used as a source of energy and nitrogen is recycled. This is an exothermic reaction, hence temperature rises.

\section{Benefits of Compost:-}

a) Composting yields a product which contains plant nutrients (1\% to $2 \%$ of NPK) as well as micronutrients which can be utilized for growth of plants.

b) The solid waste volume is very much reduced; this reduces the cost of transport \& application in the field.

c) The plant nutrients are converted to such forms that they get released gradually over a longer period \& don't get leached away easily.

d) It is known to contain trace elements such as $\mathrm{Mn}, \mathrm{Cu}$, Bo, Mo which are essential for growth of plants.

e) It is a good soil conditioner \& increases the texture of soil.

f) It improves soil tilt \& aeration, aids in root penetration, loosens soil. Adds humic acid, organic matter \& nitrogen to soil, creating more fertile soil.

g) It increases water retention and improves the ion change of soil reducing the need to irrigate.

h) It observes more radiant energy warming the soil, increasing the growth of shrubs $\&$ trees.

i) It increases the buffering capacity of the soil.

\section{Factors affecting composting process}

a) Organisms: Bacteria, actinomycetes, fungi are involved in the process.

b) Use of cultures: Innovators, enzymes hasten the composting process.

c) Moisture: Optimum is 50 to $60 \%$, less moisture content reduces metabolic activity. But more moisture content would set anaerobic conditions.

d) Temperature rises not appreciable.

e) C: $\mathrm{N}$ ratio of 30 is favourable for rapid composting.

f) Addition of sewage and sludge is done to maintain C: $\mathrm{N}$ ration at optimum levels.

g) Aeration is done to maintain oxygen rate.

\section{Methods of Composting}

Method selection is an important factor. The operational cost, capital investment, labour, space requirements and production rate decides the type of method. The composting methods can be classified into three sections:-
a) Manual method
b) Mechanical method
c) Microbial method

Manual composting can be done by Bangalore (Anaerobic) and Indore (Aerobic) method, with underground trenches and windrows respectively.

In these methods alternative layers of waste and cattle dung are used.

Some of the common types of mechanical methods are,

1. Windrow composting

a). Passive windrow

2. Aerated static pile composting

3. In-vessel composting

Windrow composting is one of the oldest and simplest methods of composting. Windrows of 8 to10ft height and 20 to $25 \mathrm{ft}$ wide at the base with a front-end loader are used. It is needed to turn the windrow once per year. High rate

systems are turned twice per week Complete composting is accomplished in 3 to 4 weeks.

Aerated static pile composting is used to compost a wide variety of organic wastes including yard waste or separated MSW. The aerated static pile system consists of aeration or exhaust piping over which the processed organic fraction of MSW is placed. Typical pile heights are about 7 to $8 \mathrm{ft}$ (2 to $2.5 \mathrm{~m}$ ). A layer of screened compost is often placed on top of the newly formed pile for insulation and odour control. Each pile is provided with an individual blower for more effective aeration control, so as to provide oxygen for biological conversion and to control the temperature within the pile. Complete composting is obtained in a period of 3 to 4 weeks.

In-vessel composting is accomplished inside an enclosed container or vessel of any shape. This is divided into two major categories; plug flow and dynamic. In plug flow system the relationship between particles in the composting mass remains same throughout the process, whereas in dynamic system the composting material is mixed mechanically during the processing. The detention period is from 1 to 2 weeks but requires 4 to 12 weeks curing period.

\section{MICROBIAL METHOD (MECHANICAL BIOLOGICAL TREATMENT)}

This is the advanced technique of solid waste management. This method works on aerobic decomposition of organic matter. In this method the generated MSW is segregated and then crushed in the shredding machine. The mega-bacillus culture and saw dust are added to the crushed waste and mixed properly. The culture consists of essential minerals and amino acids to bring about the decomposition. The mixture is then kept in pits or containers for decomposition. The final product is sieved and marketed. 


\subsection{Culture Details (4)}

Mega Bacillus (Bacillus Subtilis) also known as hay or grass bacillus is a gram-positive, catalase-positive bacterium. It is a member of genus Bacillus. It is rod-shaped and has the ability to form a tough, protective endospore, allowing the organism to tolerate extreme environmental conditions. They are resistant to ultraviolet radiation, high temperature, extreme freezing and chemical disinfectants. These produce useful enzymes like amylase, protease, cellulose, and lipase which help in decomposing the organic matter. This species is commonly found in soil, more evidence suggest that B.subtilis is a normal gut commensal in humans.

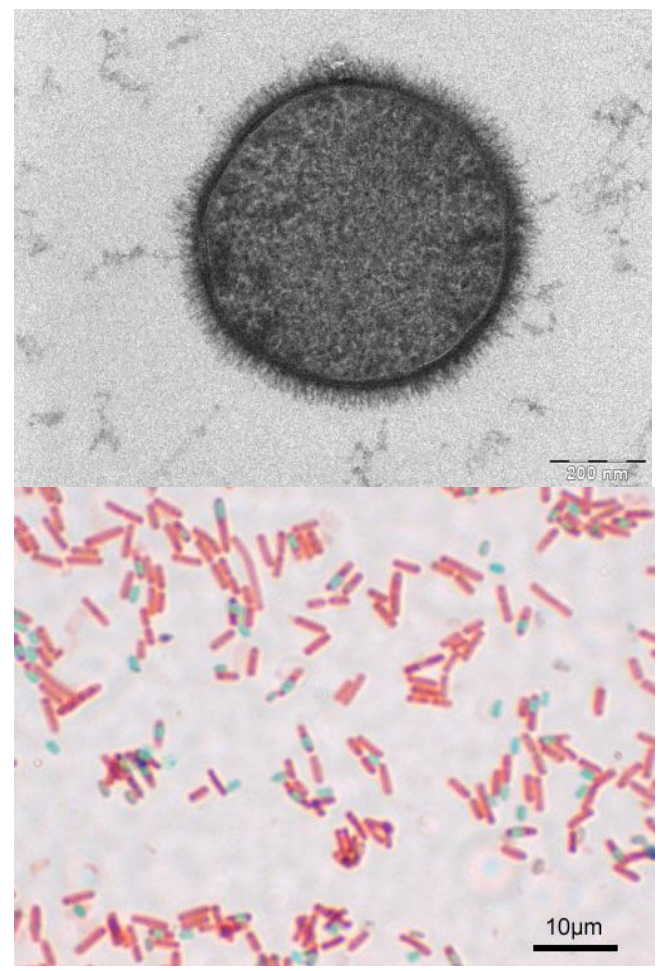

Fig-1 Bacillus Subtilis

\subsection{Advantages of use of Mega-Bacillus Culture (8)}

(9)

Apart from converting the organic matter in a eco-friendly, nutrient rich compost, there are many more advantages of mega bacillus, they are

a) Degradation of greases, fats and oil.

b) Degradation of detergent in industrial effluent and municipal sewage.

c) Degradation of cellulose matter such as the effluent of paper factory.

d) Rapid flocculation.

e) Effectively reduces BOD and COD in wastewater.

f) Keeps drain lines flowing smoothly; reduces the amount of pumping. g) Reduces offensive odours.

h) Suppresses green algae.

i) Increases population of zoo plankton.

j) Restores damaged aquatic life.

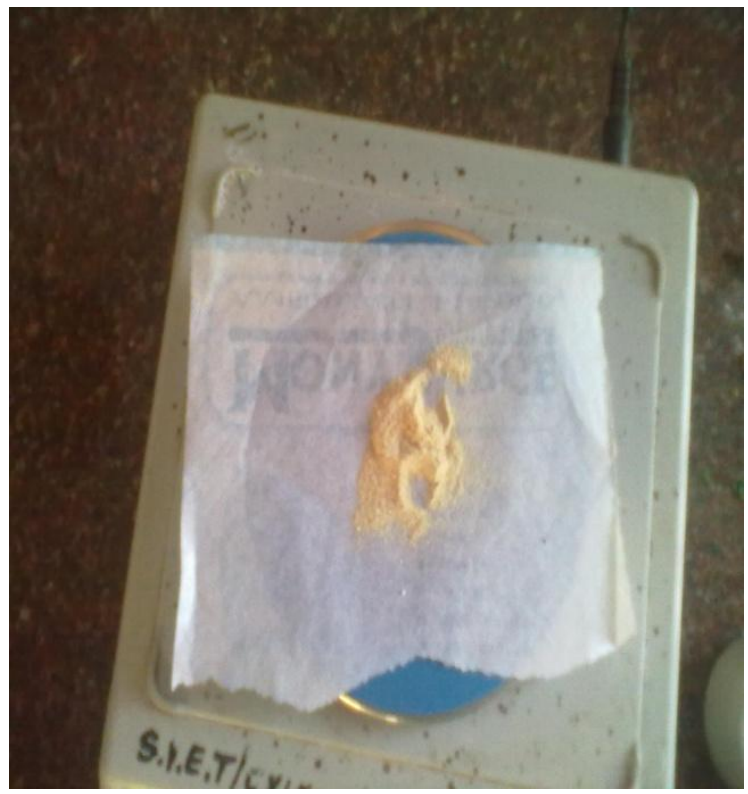

Fig-2 Mega-Bacillus Culture

\subsection{Precautions in MBT Method}

a) Regular mixing is required.

b) A moisture content of $60 \%$ is to be maintained.

c) Ideal temperature for MBT is $35^{\circ} \mathrm{C}$ to $37^{\circ} \mathrm{C}$.

\section{MBT PROCESS (8) (9)}

The waste is collected from different sectors and is segregated. The bio-degradable waste is shredded or crushed with the help of mechanical means and mixed with saw dust or baggasse, in order to maintain the moisture content to 60 to $70 \%$ approximately. The culture is mixed with waste and filled in containers and brick pits and allowed for decomposition. Regular mixing results in faster decomposition.

\section{CASE STUDY}

In this project the wastes used are, green waste (vegetable and kitchen waste).These wastes were collected from the market, canteen as well as college mess. The waste comprised of different left over putrefied vegetables such as cabbage, cauliflower, carrot, brinjal and leafy vegetables. A small amount of non-biodegradable fraction was segregated. The waste proportions used were,

1. Vegetable waste $=8.75 \mathrm{~kg}$

2. Kitchen waste $=8.33 \mathrm{~kg}$

3. Saw dust $=2.92 \mathrm{~kg}$

4. Culture $=75 \mathrm{mg}$

5 . Total $=20 \mathrm{~kg}$ (Except culture $)$ 


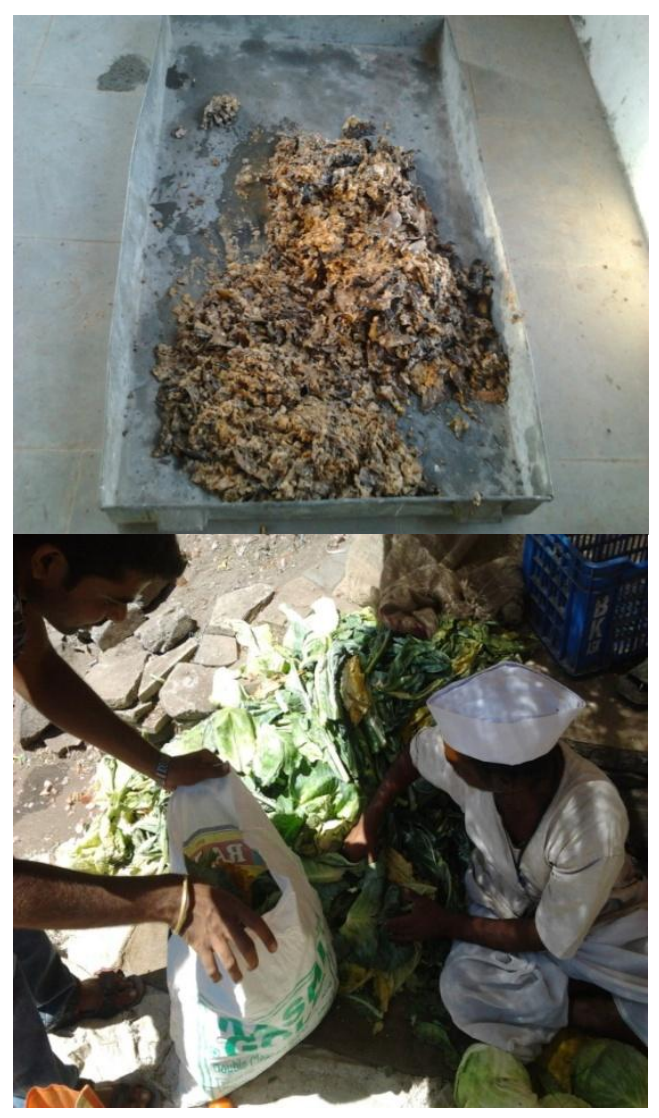

Fig-3 Collection of kitchen and vegetable waste

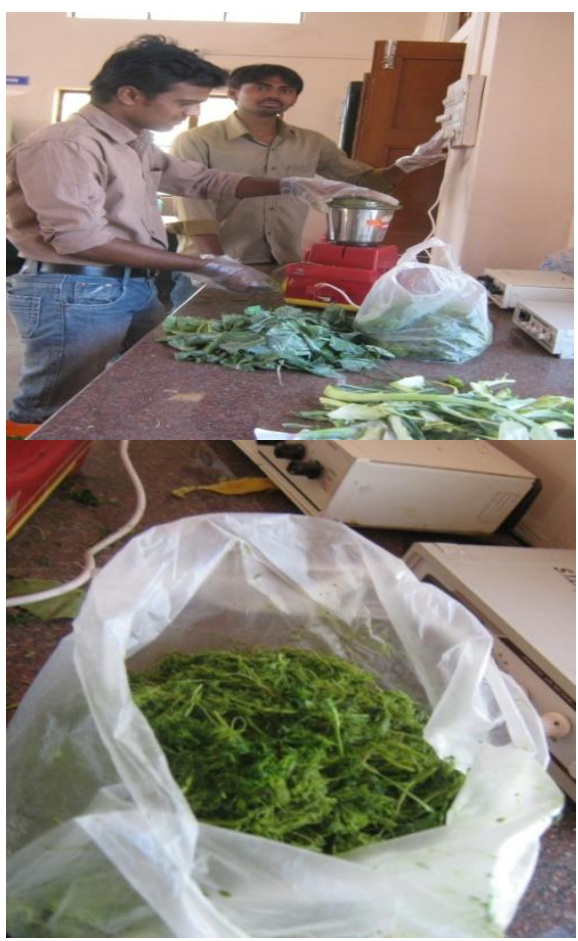

Fig-4 Shredding of the waste

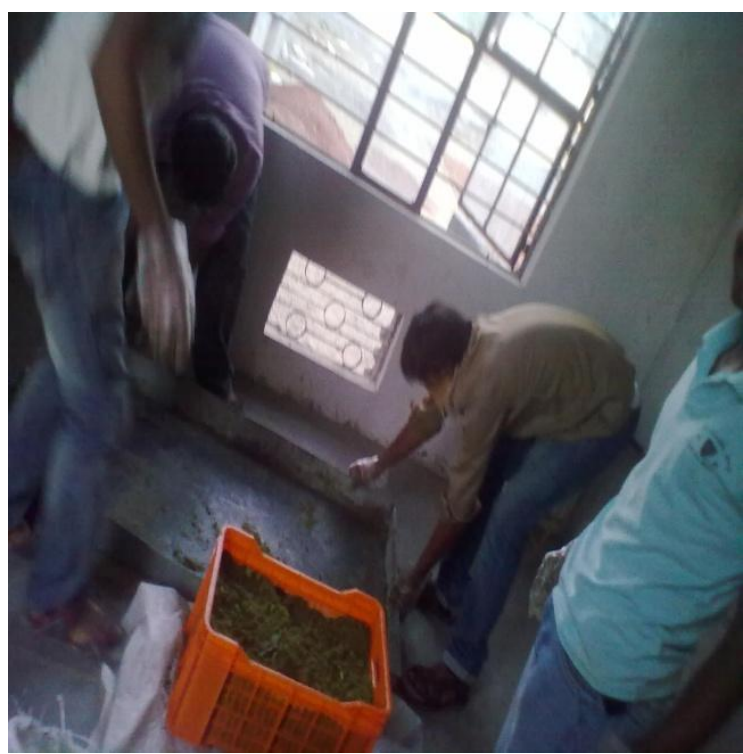

Fig-5 Mixing and placing for decomposition

Temperature was noted daily using a thermometer. Moisture content was measured by oven. The temperature observed during the starting days of composting process was $38.7^{0} \mathrm{C}$. During the decomposition process the temperature rose from $40^{\circ} \mathrm{C}$ to $60^{\circ} \mathrm{C}$ and reduced as the process reached completion. After the composting process organic carbon (OC) and major nutrients like total nitrogen $(\mathrm{N})$, total phosphorus $(\mathrm{P})$, potassium $(\mathrm{K})$, calcium $(\mathrm{Ca})$ and magnesium $(\mathrm{Mg})$ were analysed. $\mathrm{A} \mathrm{pH}$ of 9.76 was seen throughout the process.

\section{RESULTS AND DISCUSSION}

A total of $4.074 \mathrm{kgs}$ of manure was obtained after 16 days and the analysis results are as follows,

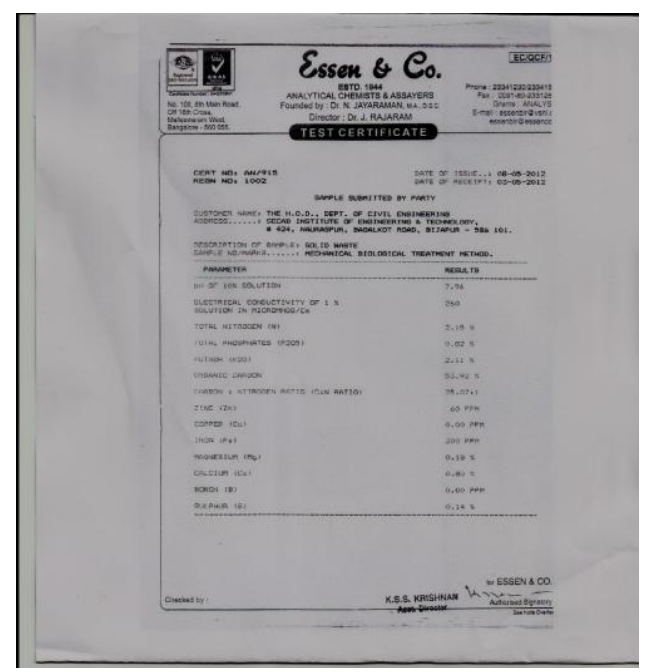

Fig-6 Analysis result 


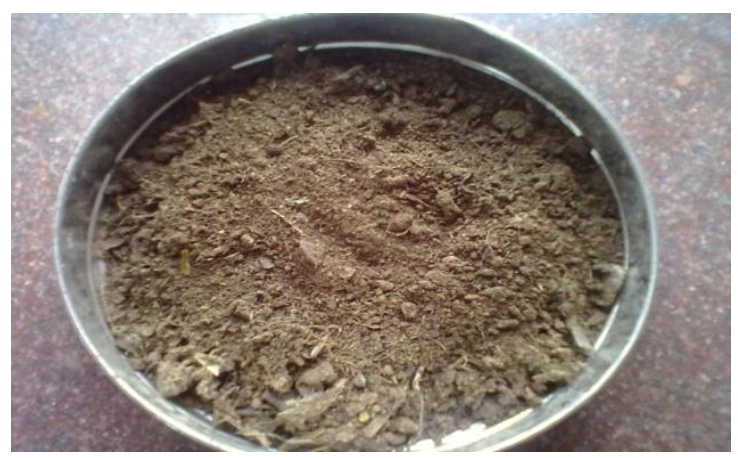

Fig-7 Final product of MBT

Table 1 Nutrient Analysis

\begin{tabular}{|c|c|c|}
\hline Sl.No & Nutrients & MBT \\
\hline 1 & $\mathrm{Ph}$ & 7.96 \\
\hline 2 & $\mathrm{EC}$ & 260 \\
\hline 3 & Total $\mathrm{N}$ & $2.15 \%$ \\
\hline 4 & Total $\mathrm{P}_{2} \mathrm{O}_{5}$ & $0.82 \%$ \\
\hline 5 & $\mathrm{~K}_{2} \mathrm{O}$ & $2.11 \%$ \\
\hline 6 & $\mathrm{OC}$ & $53.92 \%$ \\
\hline 7 & $\mathrm{C}: \mathrm{N}$ & $25.07: 1$ \\
\hline 8 & $\mathrm{Zn}$ & $60 \mathrm{ppm}$ \\
\hline 9 & $\mathrm{Cu}$ & $0 \mathrm{ppm}$ \\
\hline 10 & $\mathrm{Fe}$ & $300 \mathrm{ppm}$ \\
\hline 11 & $\mathrm{Mg}$ & $0.19 \%$ \\
\hline 12 & $\mathrm{Ca}$ & $0.8 \%$ \\
\hline 13 & $\mathrm{~B}$ & $0 \mathrm{ppm}$ \\
\hline 14 & $\mathrm{~S}$ & $0.14 \%$ \\
\hline
\end{tabular}

Checking the nutrients of compost obtained from MBT it was observed that the manure of MBT waste possessed significantly higher concentrations of the nutrients which are required for good growth of plants and the time consumed in the process was very less i.e., 16 days.

\section{ECONOMICS OF BIO-COMPOST}

This project can be started from any available fund, starting from Rs. 10,000/-. Raw materials are available easily and locally in abundance. It brings about successful organic farming, which is very easy to market. The end product biocompost based humus bio-fertilizer has multiple utility. It can be used in farms for seasonal crops, for week soil improvement, wasteland development etc. It is an EcoTechnology and the project is installed on the soil in its natural conditions, hence there is no chance of failure of the project. It is labour intensive industry; raw material is locally purchased from local suppliers thereby generating employment. Another plus point is on organic manure there is no State or Central Sales Tax. Income Tax is exempted for 10 years for industry which is producing organic manure from wastes. All biodegradables are converted into organic manure, so all villages and towns can be kept clean. The use of chemical fertilizers \& pesticides can be reduced to $50 \%$ so pollution of water and air can be reduced.

\section{LIMITATIONS}

MBT method cannot treat the waste such as pieces of plastics, polythene and polystyrene foam, iron or steel scrap. It requires machines for shredding or crushing.

\section{CONCLUSIONS}

This project is eco-friendly and one stroke solution of most of the burning problems like pollution, unemployment, development of rural area, waste land development, poor health, declining yield, improvement of soil structure, porosity, poor soil fertility and excessive use of chemical fertilizers and pesticides.

The MBT method can be successfully used to decompose the vegetable \& kitchen waste and converted into useful ecofriendly manure. It undergoes more effective aeration leading to faster decomposition and better NPK value of the manure. The amount of culture used was very less. Though initial investment is high, in the form of shredding machine it proves to be more economical in future.

\section{FUTURE SCOPE}

It has been estimated that organic resource available in our country can produce about 20 MT of plant nutrients (NPK). The five major crops paddy, jowar, wheat, bajra and maize alone are estimated to yield approximately 141.2 MT of straw and legumes add another 10 MT. An estimated domestic waste of about 25 MT, cattle manure of 320 MT and poultry manure of 3.3 MT, is generated annually in India. This tremendous agro waste and city garbage can is converted into valuable agricultural input along with a safe and clean environment.

Instead of saw dust, baggasse of sugar industry waste can also be used.

\section{REFERENCES}

[1] Applied and Environmental Soil Science Volume 2010 (2010), Article ID 967526, 13 pages doi:10.1155/2010/967526

[2] Australian journal of Basic and Applied Sciences, 3(4):3671-3676,2009, ISSN 1991-817815

[3] Centre for earth resources research \& management, Malaysia.

[4] "Effective Synthesis of Bio-Nylon materials using Bacillus", by M.Ashiuchi, 2007.

[5] "Healthcare Waste Management for primary health facilities". Centre for Renewable Energy, Appropriate Technology and Environment 
[6] Hickmann, H. Lanier, Jr. (2003). American alchemy: the history of solid waste management in the United States. ForesterPress. ISBN 978-0-9707687-2-8.

[7] Prakriti, Centre for Management Studies, Dibrugarh University.

[8] Sanitization and composting of municipal solid wasteby J.M.S. Biotech Pvt.ltd Mysore.

[9] Site visit to Save environment engineers pvt.ltd Pune and actual details are collected from the unit.

[10] Solid waste management in developing countries- by A.D.Bhide, B.B. Sudaresan.

\section{BIOGRAPHIES}

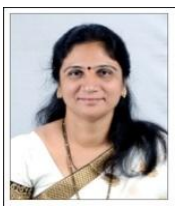

Prof (Smt) A.S.Tanksali , M.Tech (Env), working as Asst. Prof in Civil Engg Dept of BLDEA's CET, Bijapur

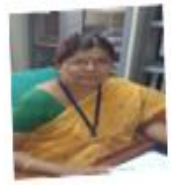

Prof (Smt) S.S.Angadi , M.Tech (Strs), working as Asso. Prof/HOD in Civil Engg Dept of BLDEA's CET, Bijapur

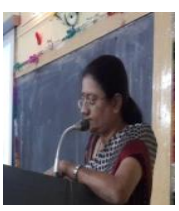

Prof (Smt) A.S.Arwikar , M.Tech (Env), working as Asso. Prof. in Civil Engg Dept of BLDEA's CET, Bijapur 